- then we are probably okay," he says.

However, that does not mean the danger would be over, Cressman warns. Wind could still carry the locusts across the Red Sea and into northern Sudan (see 'Breeding grounds'), where the wet season typically runs from July until September. Although fighting continues between government troops and militias in the Darfur region, Cressman says that agricultural officials there should be able to control locusts throughout most of northern Sudan.

Locust controllers can call on increasingly sophisticated tools, including regional weather forecasting and satellite imagery for tracking rainfall and vegetation as well as hand-held global-positioning-system devices to monitor progress in the field. Orbiting sensors can identify pockets of vegetation hidden at the base of sand dunes and along ephemeral streams, says

\section{BREEDING GROUNDS}

Locusts moving from the Red Sea coast could find the water and food they need to breed - then potentially swarm - in Yemen or Sudan.

E G Y P T

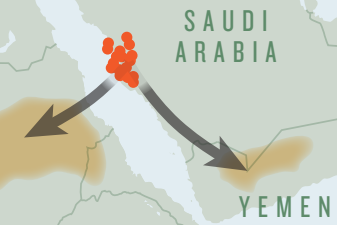

SUDAN

Pietro Ceccato, a remote-sensing scientist at the International Research Institute for Climate and Society who works with the FAO's locust team at Columbia University's LamontDoherty Earth Observatory in New York.

Ceccato, who developed the current method for detecting vegetation using NASA's Moderate Resolution Imaging Spectroradiometer sensor and similar platforms, says that the FAO is now working with field teams in Algeria to test the sensitivity of their methods. The aim is to spot pockets of plant growth by combining a measure of the 'greenness' of an area with infrared data that reveal water content. "We want to know how small is the smallest patch of vegetation that we can detect," he says.

Technology is helpful, Cressman says, but not sufficient. "The idea is that if we can detect the outbreaks and then control them, then we won't have a situation like we had in 2004," he says, "but that will depend on individual countries, politics, security and all those things." -

\title{
Stem-cell scientists grapple with clinics
}

\section{In the absence of regulation, researchers weigh their options for educating patients about unproven treatments.}

\section{BY HEIDI LEDFORD}

$\mathrm{W}$ hen stem-cell clinics are asked for documentation about the treatments they offer, some are quick to produce letters from lawyers instead. In the face of legal threats from clinics, the International Society for Stem Cell Research (ISSCR) has suspended a service intended to help patients wade through claims about therapies. It is now pondering its next move.

For stem-cell researchers, the worldwide proliferation of clinics offering regenerative medicine is frustrating. Many of the treatments such clinics offer - injecting a patient's own stem cells back into his or her body in a bid to treat conditions ranging from Parkinson's disease to spinal-cord injuries - are at best a waste of money, and at worst dangerous. "There's real potential to damage the legitimacy of the field," says Timothy Caulfield, who studies health law and policy at the University of Alberta in Edmonton, Canada.

Last June, the ISSCR, which is based in Deerfield, Illinois, launched its 'Submit a Clinic' website in an effort to educate patients. "Have you seen an advertisement for a stem cell clinic or other stem cell treatment provider and want to know more about it?" the site asked, and invited users to submit the names of centres.

The ISSCR offered to find out whether providers had medical-ethics committees and were overseen by a regulatory agency such as the US Food and Drug Administration (FDA) or the European Medicines Agency. The answers were to be posted on the society's website.

But some of the initial inquiries drew letters from lawyers, challenging the society's authority to question the clinics. Elaine Fuchs, a stem-cell researcher at Rockefeller University in New York and former president of the ISSCR, says that the society sought legal advice and was

\section{"There's real potential to damage the legitimacy of the field."} assured that it stood on firm ground. Even so, she says, everyone recognized that lawsuits would quickly drain the society's limited resources.

In February, the ISSCR shelved the project. At the society's annual meeting in Toronto, Canada, this month, Irving Weissman, a stem-cell researcher at Stanford University in California, turned to the audience for advice. "What should we do?" he asked. "Should we risk litigation?" The audience could not come to a consensus, and the programme is still on hold.

Some researchers worry that patients will now turn for guidance to the International
Cellular Medicine Society (ICMS) in Salem, Oregon - an organization of patients and physicians, some of whom have close ties to the regenerative-medicine industry. The ICMS, which offers accreditation to stem-cell clinics, was co-founded by the medical director of Regenerative Sciences, a clinic based in Broomfield, Colorado. Last August, the FDA requested a federal injunction against Regenerative Sciences for failing to adhere to proper manufacturing standards (see Nature 466, 909; 2010).

Clinics operate without controls in many countries. In May, Germany shut down a notorious stem-cell clinic linked to the death of a toddler and the near-death of a ten-year-old boy, but other centres offering unproven treatments remain open around the world. In the United States, clinics have tended to escape regulation. The FDA steps in only if the treatment fits certain criteria - for instance, if the agency determines that the stem cells are significantly manipulated after being extracted, or if they are being used in a patient other than the donor.

Fuchs emphasizes that the ISSCR still has options for educating patients and policymakers about the risks of unproven treatments. Its website lists questions that patients should ask when evaluating a clinic, and the society is discussing ways to educate the media, which sometimes gives uncritical coverage to such clinics (A. Zarzeczny et al. Nature Biotechnol. 28, 1243-1246; 2010). It already has plans to target primary-care physicians, says Caulfield; the ISSCR hopes to publish an article on stem-cell clinics in Canadian Family Physician, a medical journal sent to every general practitioner in Canada, he notes.

In the meantime, stem-cell researchers face a steady stream of e-mails seeking advice about clinics. Caulfield responds to these inquiries cautiously, mindful of the threat of litigation. "And I'm a little bit cowardly when I write articles about this," he says. "I don't mention the clinics by name." - 